\title{
Noktasal ve yayılı kirletici kaynaklarının yüzeysel su kalitesi üzerinde etkisi, Alaşehir Çayı alt havzası örneği
}

\author{
The effect of point and diffuse pollution sources on surface water quality, \\ A case study for Alaşehir Aiver sub-basin
}

\author{
B. Hande GÜRSOY HAKSEVENLER ${ }^{* 1, a}$, Selma AYAZ ${ }^{2, b}$ \\ ${ }^{I}$ Marmara Üniversitesi, Siyasal Bilgiler Fakültesi, Kamu Yönetimi Bölümü ve \\ Kent Sorunlart ve Yerel Yönetimler Araştırma ve Uygulama Merkezi, 34820, Istanbul \\ ${ }^{2}$ TÜBİTAK Marmara Araștırma Merkezi, Çevre ve Temiz Üretim Enstitüsü, 41470, Kocaeli
}

• Geliş tarihi / Received: 18.02.2021 • Düzeltilerek geliş tarihi / Received in revised form: 23.08.2021 • Kabul tarihi / Accepted: 11.09 .2021

\begin{abstract}
$\ddot{O} z$
Bu çalışmada nüfusu, gelişen sanayisi ve tarım faaliyetleri dikkate alınarak Alaşehir Çayı Alt Havzası pilot bölge olarak seçilmiş, havzadaki noktasal ve yayılı kaynaklardan gelen kirliliğin yüzey suyu kalitesine etkisinin incelenmesi hedeflenmiştir. Noktasal kaynaklı kirleticiler olarak alıcı ortama gelen kentsel ve endüstriyel atıksular; yayılı kaynaklı kirleticiler olarak gübre kullanımı, hayvancılık faaliyetleri, arazi kullanımı, katı atık sızıntı suları, fosseptik kullanımı ve atmosferik taşınım dikkate alınmıştır. Bu kaynaklardan gelen azot ve fosfor yüklerinin hesaplanması için basit ve kolay uygulanabilir bir metodoloji sunulmuştur. Söz konusu kirletici kaynakların yüzeysel su kalitesine etkisini belirlemek için 2015-2016 yıllarında dört dönem boyunca izleme yapılmıştır. Yapılan izlemeler Yerüstü Su Kalitesi Yönetmeliği (10.08.2016, RG: 29797) Ek 5, Tablo 2'de yer alan konvansiyonel parametreler üzerinden değerlendirilmiştir. Elde edilen sonuçlar ışığında havzada oluşan toplam TN ve TP yükünün önemli bir kısmının (TN'un \%79'u, TP'un \%61'i) yayılı kaynaklı faaliyetlerden geldiği belirlenmiştir. Yayılı kirliliğe en fazla sebep olan kaynaklar gübre kullanımı (toplam yayılı TN'nin \%37'si, TP'nin \%48'i) ve hayvanc1lı faaliyetleridir (toplam yay1lı TN'nin \%34'ü, TP'nin \%41'i). Noktasal kirliliğin ise belirgin olarak kentsel atıksu deşarjlarından kaynaklandığg (toplam noktasal TN'nin \%93'ü, TP'nin \%95'i ve KOİ'nin \%83'ü) belirlenmiştir. Havzadaki yüzeysel su kalitesi genel olarak çok kirli (Sınıf IV) ve kirli (Sınıf III) olarak belirlenmiştir. Organik kirleticilerin kaynağının noktasal kirleticiler olduğu tespit edilmiştir. Noktasal ve yayılı kirletici kaynakların bulunduğu alanlardan geçen akarsuyun su kalitesi belirgin ölçüde kötüleşmektedir.
\end{abstract}

Anahtar kelimeler: Noktasal kaynaklı kirlilik, Su kalitesi, Toplam azot, Toplam fosfor, Yayılı kaynaklı kirlilik.

\begin{abstract}
In this study, Alaşehir River Sub-basin was selected as a pilot area considering its population, developing industry and agricultural activities, and it was aimed to examine the effect of pollution from point and diffuse sources on surface water quality. Urban and industrial wastewaters coming to the receiving environment were considered as point source pollutants while fertilizer use, livestock activities, land use, solid waste leachate, septic tank use and atmospheric convection were considered as diffuse source pollutants. A rough and easily applicable methodology was presented for calculating nitrogen (total nitrogen, TN) and phosphorus (total phosphorus, TP) loads from these sources. For determining the impact of these pollution sources on surface water quality, main streams of the basin were monitored for four periods in 2015-2016. The obtained results were evaluated over the conventional parameters in Table 2 of Annex 5 of the Surface Water Quality Regulation (10.08.2016, RG: 29797). In the light of the results, a significant part of the total TN and TP load (79\% of TN, 61\% of TP) occurred in the basin came from activities with diffuse sources. The major sources of diffuse pollution were fertilizer use (37\% of TN, 48\% of TP) and livestock activities (34\% of TN, 41\% of TP). Point source pollution was mostly caused by urban wastewater discharges (93\% of TN, 95\% of TP and 83\% of COD). The surface water quality was generally defined as highly polluted (Class IV) and polluted (Class III). In the presence of organic parameters, point source pollutants were found as responsible for pollution. The water quality of the streams passing through the areas with point and diffuse pollutant sources deteriorated significantly.
\end{abstract}

Keywords: Point source pollution, Water quality, Total nitrogen, Total phosphorus, Diffuse source pollution.

\footnotetext{
${ }^{* a}$ B. Hande GÜRSOY HAKSEVENLER; hande.gursoy@marmara.edu.tr; Tel: (0216) 777 42 66; orcid.org/0000-0003-3711-5058

${ }^{\mathrm{b}}$ orcid.org/0000-0001-5932-9060
} 


\section{Giriş}

Günümüzde nüfusun hızlı artışı, sanayileşme ve kentleşme ile kullanılabilir nitelikteki suyun miktarında ve kalitesinde önemli azalmalar tespit edilmektedir (du Plessis, 2019). Ülkemiz özelinde su varlığ 2020 y1lında $1346 \mathrm{~m}^{3} /$ kişi.yıl olarak belirlenmiştir (DSİ, 2021). Su kaynaklar1 üzerindeki baskıyı ifade eden Falkenmark indeksine göre ülkemiz "su sıkıntısı çeken ülkeler" sinıfindadır (Falkenmark, 1989). Ayrica Türkiye'nin içinde bulunduğu Akdeniz Havzası iklim değişikliğinden olumsuz etkilenmekte, daha kötü bir senaryoyla ülkemizin 2040 y1lında "su kıtlığı çeken ülkeler" içinde yer alması tahmin edilmektedir (Luo vd., 2015). Su kaynaklar1 üzerindeki bu değerlendirmeler incelendiğinde, su kaynaklarının havza ölçeğinde yönetimi daha da önem kazanmaktadır. Havza kavramı idari sınırdan bağımsız olarak, akarsuyun başlangıcından döküldüğü noktaya kadar tüm drenaj alanının kapsamaktadır. Bu alanda su kaynağının miktar ve nitelik açısından korunması, sürdürülebilir kullanımı ve geliştirilmesi için havza yönetiminin yapılmas1 gerekmektedir.

$\mathrm{Su}$ kaynaklarındaki kalitenin iyileştirilmesi ve korunması için noktasal ve yayılı kirleticilerin belirlenmesi ve kontrolü ilk adımı oluşturmaktadır. Söz konusu kaynaklardan gelen kirliliğin belirlenmesinde birim kirlilik yüklerine dayalı basit hesaplamalardan çeşitli hassasiyetteki kompleks modellere kadar pek çok yöntem kullanılmaktadır (Gürel vd., 2011; Tanık vd., 2013; Carneiro vd., 2020). Özellikle yayılı kaynaklı kirleticiler, arazi kullanımı, tarım ve hayvancılık faaliyetleri, 1sınma ve endüstriyel faaliyetler sonucu oluşan kirletici emisyonlarından kaynaklanmakta; iklime, meteorolojik koşullara, coğrafi ve jeolojik duruma bağlı olarak kesikli şekilde alıcı ortamlara karmaşık taşınım ve dönüşüm reaksiyonları ile ulaşmaktadır (Özalp, 2009). Dolayısıyla noktasal kirlilik yükleri ile karşılaştırıldığında hesaplanmaları yerine ancak tahminlere dayalı olarak belirlenebilmektedir. Yay1lı yükün belirlenmesinde kullanılan basit hesaplama yöntemleri ile az veriyle ve kısa sürede tahmini yük değerine ve bunun havzadaki dağılımına ulaşılabilmektedir. Öte yandan kompleks simülasyon modelleri ile yeterli mekânsal ve zamansal çözünürlükle daha gerçekçi sonuçlar üretilebilmektedir. Bununla birlikte, bu modelleri çalıştırmak için havzanın fiziksel özelliklerini tanımlayan kapsamlı verilere, modelleri doğrulamak için akarsuların su kalitesi ve debi verilerine ihtiyaç duyulmaktadır. Dahası, uzmanlık gerektirdiklerinden bu modeller üzerinde çalışmak genellikle zor olmakta ve uygulamaları genellikle kısa süreli çalışmalarda pratik olmamaktadır (Gürel vd., 2011). Kirletici kaynaklar arasında azot ve fosfor gibi besi maddeleri sucul ortamda ötrofikasyona sebep olarak, sucul ekosistemlerin sağlı̆̆ını tehdit etmektedir (Carpenter, 2005). Su kalitesinin izlenmesinde kullanılan en önemli göstergelerden biri suyun ötrofik seviyesidir (Smith, 2003). Buna bağlı olarak farklı kirlilik senaryolarına göre çalıştırılan havza ve su kalitesi modellerinde temel kirlilik girdilerini besi maddeleri oluşturmaktadır (Özcan vd., 2016; Ouyang vd., 2017).

$\mathrm{Su}$ kalitesinde tespit edilen azot ve fosfor kirliliğinin kaynağ 1 hem noktasal hem de yayılı olabilmektedir. Ancak literatürdeki çalışmalar incelendiğinde çalışmaların çoğunun ya su kalitesinin belirlenmesi üzerine olduğu (Zeydan vd., 2019; Verep vd., 2020; Y1ldırım, 2020) ya da kirletici kaynaktan gelen kirliliğin belirlenmesi üzerine olduğu (Akdoğan vd., 2015; Hacısalihoğlu ve Karaer, 2020) görülmektedir. Kirlilik kaynăg 1 ile su kalitesi arasında ilişki kurulmasına ancak birkaç çalışmada değinildiği tespit edilmektedir (Ayyıldız, 2019; Eren ve Kaya, 2020). Bu çalışmada Gediz Havzası içinde yer alan Alaşehir Çayı Alt Havzası barındırdığı yoğun nüfusla, hızlı endüstrileşmesi ve aynı zamanda önemli tarımsal faaliyetleri sebebiyle pilot havza olarak seçilmiştir. Alt havza bazında noktasal ve yayılı kaynaklı kirleticilerin bölgeyi ne ölçüde kirlettiklerinin belirlenmesi için toplam azot (TN) ve toplam fosfor (TP) yükleri üzerinden basit bir hesaplama yaklaşımı geliştirilmiştir. Söz konusu kirleticilerin yüzeysel su kalitesini ne ölçüde kirlettikleri Yerüstü Su Kalitesi Yönetmeliği (YSKY, Mülga OSİB, 2016) Ek 5 Tablo 2'de yer alan parametreler ve sınır değerler üzerinden ortaya konmuştur.

\section{Materyal ve metot}

\section{1. Çalışma alanı}

Alaşehir Çayı Alt Havzası, Ege Bölgesinin en önemli havzaları arasında sayılan Gediz Havzası sınırları içindedir. Alt havza Alaşehir Çayı'nı içine alıp, Gediz Nehri ile birleşerek Manisa Merkez ilçeye kadar olan kısmı kapsamaktadır Alt havzayı oluşturan başlica yerleşimler Manisa iline ait Alaşehir, Salihli, Sarıgöl, Ahmetli ve Turgutlu ilçeleridir. Alt havza $379769 \mathrm{~km}^{2}$ 'lik alanı ile Gediz Havzası'nın \%22'sini oluşturmakta, yaklaşık 402000 kişi ile Gediz Havzası'nın \%25'ini barındirmaktadır (OSIB, 2013, Hazırlayan: TÜBITTAK MAM). 
Alt havzada yer alan yerleşimlerden Alaşehir, Ahmetli, Durasill, Turgutlu ve Salihli'de kentsel Atıksu Arıtma Tesisi (KAAT) mevcut olup, bu tesislerden Alaşehir KAAT ihtiyaca cevap vermemiş, Kasım 2020'den itibaren yeni KAAT işletmeye alınmıştır. Ancak mevcut hesaplamalarda henüz yeni tesisin işletmeye alınmadığ 1 kabulü üzerinden gidilmiştir. Sarıgöl ilçesinde KAAT bulunmamaktadır. Endüstri olarak Salihli OSB ve Salihli Dericiler ile gıda ve içecek üretimi yapan tesisler yer almaktadır. Turgutlu'da yer alan Turgutlu OSB'de henüz atıksu arıtma tesisi (AAT) bulunmayıp, oluşan atıksular arıtılmadan Nif Çayı'na ardından Gediz Nehrine ulaşmaktadır. Diğer bir ifadeyle Turgutlu ilçesi Alaşehir Çayı Alt Havzasında bulunsa bile ilçedeki endüstriyel atıksularının önemli bir kısmı Gediz Havzasına ait diğer bir alt havzaya deşarj edilmektedir. Alt havzada oluşan katı atıklar mevcut durumda düzensiz olarak depolanmaktadır. Yakın zamanda Turgutlu, Sarı̈öl ve Alaşehir ilçelerinde katı atık transfer istasyonları işletmeye alınacak olup, toplanan atıklar Manisa Merkezde yer alan Uzunburun Katı Atık Bertaraf ve Düzenli Depolama Tesisinde bertaraf edilecektir.

Gediz Havzası geneli verimli toprakları ve iklimi ile tarıma oldukça elverişlidir. Alaşehir Çayı Alt Havzasında yer alan Alaşehir, Salihli ve Turgutlu ilçeleri ile birlikte alt havza dişında yer alan Gediz ve Menemen ilçelerinde yapılan tarımsal üretim, Türkiye'deki üretimin \%10'u karşıllık gelmektedir. Buna bağlı olarak gübre ve zirai ilaç kullanımının yoğun olduğu görülmektedir. Diğer taraftan hayvancilık faaliyetlerinde Salihli, Turgutlu ve Alaşehir ilçeleri büyükbaş, küçükbaş ve kümes hayvanı yetiştiriciliğinde ve hayvansal üretimde öne çıkmaktadır.

\subsection{Noktasal kaynakl kirlilik yüklerinin hesaplanmasl}

Noktasal kaynaklardan gelen kirlilik yükü hesaplamalarında alıcı ortamlara deşarj edilen kentsel atıksular ile endüstriyel atıksular (arıtıldıktan sonra ve/veya arıtılmadan) dikkate alınmıştır. Kentsel atıksulardan kaynaklanan kirliliğin belirlenmesinde "kirlilik yükleri" ve "atıksu debileri" için 20.03.2010 tarih ve 27527 sayılı Atıksu Arıtma Tesisleri Teknik Usuller Tebliği'nde yer alan Tablo 2.1 değerlerinden yararlanılmıştır (Mülga ÇOB, 2010). Havzadaki tüm yerleşim yerlerinde kanalizasyon şebekesinin var olduğu kabul edilmiştir. Mevcut kentsel atıksu arıtma tesislerindeki kirlilik giderme verimleri organik madde (kimyasal oksijen ihtiyac1 üzerinden, KOİ) için \%80, TN için \%25, TP için
$\% 10$ olarak alınmıştır. Eğer mevcut KAAT'lerde azot ve fosfor giderimi varsa kirlilik giderme verimleri KOİ için \%80, TN için $\% 70$, TP için $\% 70$ olarak hesaplanmıştır. Eğer yerleşim yerinde fosseptik kullanılıyorsa, bunun sızdırmalı olduğu kabul edilerek kirlilik giderim verimleri; KOİ için $\% 50$, TN için $\% 20$ ve TP için \%30 olarak belirlenmiştir (Öztürk, 2008). Bunların dışında havzada kentsel alan içerisindeki sanayi tesislerinden kaynaklanan yüklerin (bir diğer ifadeyle KAAT'ne gelen endüstriyel atıksulardan kaynaklanan yüklerin) hesaplamaya dahil edilmesi için, kentsel kirlilik yükleri $\% 25$ oranında artırılmıştır.

Endüstriyel kirliliğin belirlenmesinde havzada önemli kirletici etkisi olan ve atıksuyunu alıc1 ortama deşarj eden işletmeler dikkate alınmıştır. $\mathrm{Bu}$ işletmelere ait debi değerleri Manisa İli Çevre ve Şehircilik Müdürlüğü'nden temin edilmiştir. Kirletici konsantrasyonları belirlenirken işletmelerin deşarj izinlerinin olup olmadığı dikkate alınmıştır. Deşarj izni olan tesislerin kirletici konsantrasyonları için $\mathrm{Su}$ Kirliliği Kontrolü Yönetmeliği'nde (SKKY, 31.12.2004 tarihli ve 25687 sayıll, (Mülga ÇOB, 2004) yer alan tesislerden işletmenin ilgili olduğu tablodaki değerler kullanılmıştır. Deşarj izni olmayan tesisler için SKKY'deki ilgili sektör tablosu esas alınarak tabloda verilmiş olan sınır değerler üzerinden arıtma tesisinin KOİ için \%80, TN için $\% 35$ ve TP için \%15 giderim yapacağ 1 kabul edilerek hesaplamalar yapılmıştır (Öztürk, 2008). Çalışmada verisi elde edilemeyen tesislerden gelecek debi ve kirlilik yükü için endüstrilerden kaynaklanan kirlilik yükleri $\% 25$ oranında artırılmıştır (OSİB, 2013, Hazırlayan: TÜBİTAK MAM).

\subsection{Yayılı kaynaklı kirlilik yüklerinin hesaplanmasl}

Çalışma kapsamında havzadaki başlıca yayılı kirletici kaynakları "arazi kullanımı, tarımsal faaliyetler (gübre kullanımı), hayvancılık faaliyetleri, atmosferik taşınım, katı atık depolama faaliyetleri (düzensiz depolama alanı sızıntı suları), fosseptik (sızdırmalı) çıkış suları" olarak sınıflandırılmıştır. İzlenen metodolojide arazi kullanım dağılımı ve her bir arazi kullanım faaliyetinin alansal değerleri 2012 y1lı Landsat uydu görüntüsü ile belirlenmiştir. Ayrıca sayısallaştırılmış $1 / 25.000$ ölçekli toprak ve standart topografik haritalar da diğer önemli veri toplama kaynakları olarak kullanılmıştır. 
Yayılı kaynaklı kirlilik parametreleri olarak TN ve TP dikkate alınarak hesaplamalar yapılmıştır. Bilindiği gibi birim yükler büyük ölçüde iklim koşullarına, toprak özelliklerine, nüfus eğilimine, tarımsal uygulamalara ve kültüre vb. bağlidır. Mevcut çalışmada her bir kirlilik kaynağının birim yükleri, literatürde belirtilen değerler üzerinden seçilmiş, kullanılan veriler ilgili kurumlardan temin edilmiştir. Yayılı kirliliğin belirlenmesinde dikkate alınan faaliyetler ve birim yükler Tablo 1 'de sunulmaktadır.

Tablo 1. Yayılı kirliliğin belirlenmesinde kullanılan birim yükler

\begin{tabular}{|c|c|c|c|c|}
\hline Faaliyet & \multicolumn{2}{|c|}{ Birim yükler } & \multirow[t]{2}{*}{ Veri kaynağg } & \multirow[t]{2}{*}{ Birim yük kaynağı } \\
\hline Arazi kullanımı & TN (kg/ha.yıl) & TP (kg/ha. yıl) & & \\
\hline Kırsal Alanlar & 9.5 & 0.90 & CORINE, 2012 & Dahl ve Kurtar, 1993; \\
\hline Orman Alanları & 2 & 0.05 & & ÖEJV, 1993 \\
\hline Cayır ve Meralar & 5 & 0.1 & & \\
\hline Kentsel Alanlar & 3 & 0.50 & & \\
\hline Hayvancılık faaliyetleri & $\begin{array}{c}\text { TN } \\
\text { (kg/ton hayvan } \\
\text { ağırlığı.gün) }\end{array}$ & $\begin{array}{c}\text { TP } \\
\text { (kg/ton hayvan } \\
\text { ağırlığı.gün) } \\
\end{array}$ & & \\
\hline $\begin{array}{l}\text { Büyükbaş (inek, sığır) } \\
(\approx 500 \mathrm{~kg})\end{array}$ & 0.30 & 0.10 & TÜİK, 2016 & $\begin{array}{l}\text { Agricultural Statistics, } \\
\text { 2001; Andreadakis vd., }\end{array}$ \\
\hline $\begin{array}{l}\text { Küçükbaş (koyun, keçi) } \\
(\approx 45 \mathrm{~kg})\end{array}$ & 0.42 & 0.06 & & 2007; Öztürk, 2008 \\
\hline $\begin{array}{l}\text { Kümes Hayvanı (tavuk) } \\
(\approx 2 \mathrm{~kg})\end{array}$ & 0.52 & 0.22 & & \\
\hline Tarımsal faaliyetler & TN (-) & TP (-) & & \\
\hline Gübre Kullanımı & $\% 10$ & $\% 2.5$ & $\begin{array}{l}\text { CORINE, 2012; } \\
\text { Mülga Gıda Tarım } \\
\text { ve Hayvancılık } \\
\text { Bakanlığ1, 2015 }\end{array}$ & $\begin{array}{l}\text { Oenema ve Roest, } \\
\text { 1998; Bottcher ve } \\
\text { Rhue, 2000; Öztürk, } \\
2008 \\
\end{array}$ \\
\hline Katı atık sızıntı suyu & TN (mg/L) & TP (mg/L) & & \\
\hline $\begin{array}{l}\text { (Bölgedeki yağış dikkate } \\
\text { alınarak) }\end{array}$ & 400 & 10 & $\begin{array}{c}\text { TÜİK, } 2016 \\
\text { Meteoroloji Genel } \\
\text { Müdürlüğü, } 2016\end{array}$ & Öztürk, 2008 \\
\hline Atmosferik taşınım & TN (kg/ha.yıl) & TP (kg/ha.yıl) & & \\
\hline $\begin{array}{l}\text { (Bölgedeki yağış dikkate } \\
\text { alınarak) }\end{array}$ & 10.3 & - & $\begin{array}{l}\text { Meteoroloji Genel } \\
\text { Müdürlüğü, 2016; } \\
\text { CORINE, 2012 }\end{array}$ & Öztürk, 2008 \\
\hline Fosseptik kullanımı & TN (gr/kişi.gün) & TP (gr/kişi.gün) & & \\
\hline & 4.8 & 0.7 & $\begin{array}{c}\text { TÜİK, 2016; Atıksu } \\
\text { Arıtma Tesisleri } \\
\text { Teknik Usuller } \\
\text { Tebliği, } 2010\end{array}$ & Öztürk, 2008 \\
\hline
\end{tabular}

Yayılı kirlilik, meteorolojik, iklimsel, coğrafi ve jeolojik koşullara bağlı olan taşınma ve dönüşüm reaksiyonları ile alıcı ortamlara ulaşmaktadır. $\mathrm{Bu}$ nedenle kirliliğin bir kısmının alıcı ortama ulaşacağı kabul edilmektedir. Alıcı ortama ulaşan gübre kullanımı ve hayvancılık faaliyetleri ile ilgili literatürde azot için \%5-30, fosfor için \%0.5-5 değerleri yer almaktadır (Oenema ve Roest, 1998; Bottcher ve Rhue, 2000). Ertürk ve vd., (2007)'nin Melen Havzasında nütrient emisyonlarının belirlenmesi üzerine yaptıkları çalışma dikkate alınarak, mevcut çalışmada bu değerler $\mathrm{TN}$ için $\% 15$, TP için \%5 olarak seçilmiștir. Alıcı ortama ulaşan yayılı kirlilik yükü oranları Tablo 2'de yer almaktadır.
Tablo 2. Alıcı ortama ulaşan yayılı kirlilik yüklerinin yüzdesi (\%)

\begin{tabular}{lcc}
\hline Yayılı kirlilik kaynakları & TN (\%) & TP (\%) \\
\hline Tarımsal faaliyetler & 15 & 5 \\
Hayvancılık faaliyetleri & 15 & 5 \\
Fosseptik kullanımı & 80 & 70 \\
Atmosferik taşınım & 5 & - \\
\hline
\end{tabular}

\subsection{Su kalitesinin belirlenmesi}

Çalışma kapsamında, Alaşehir Çayı ve bağlandığ 1 Gediz Nehri üzerinde 11 istasyon 2015-2016 döneminde 4 mevsim olarak izlenmiştir. İzleme istasyonlarının belirlenmesinde, ana kolu ve yan kolları temsil edecek şekilde akarsuyun başı, sonu ve bağlanma noktaları öncesi ve sonrası dikkate alınmıştır (Şekil 1). 
Analizler, TÜBİTAK MAM Çevre ve Temiz Üretim Enstitüsü'nün akredite $\mathrm{Su}$ ve Atıksu Laboratuvarlarında gerçekleştirilmiştir. Proje kapsamında yapılan izleme çalışmalarında, numune alımı ve analizler için izlenen yöntemler, uluslararası standart yöntemlerdir. Analizler Tablo 3'te belirtilen yöntemlere göre ve belirtilen cihazlarla gerçekleştirilmiştir. İzleme sonuçları YSKY Ek-5 Tablo 2 (kıtaiçi sular için)'ye göre değerlendirilmiştir.

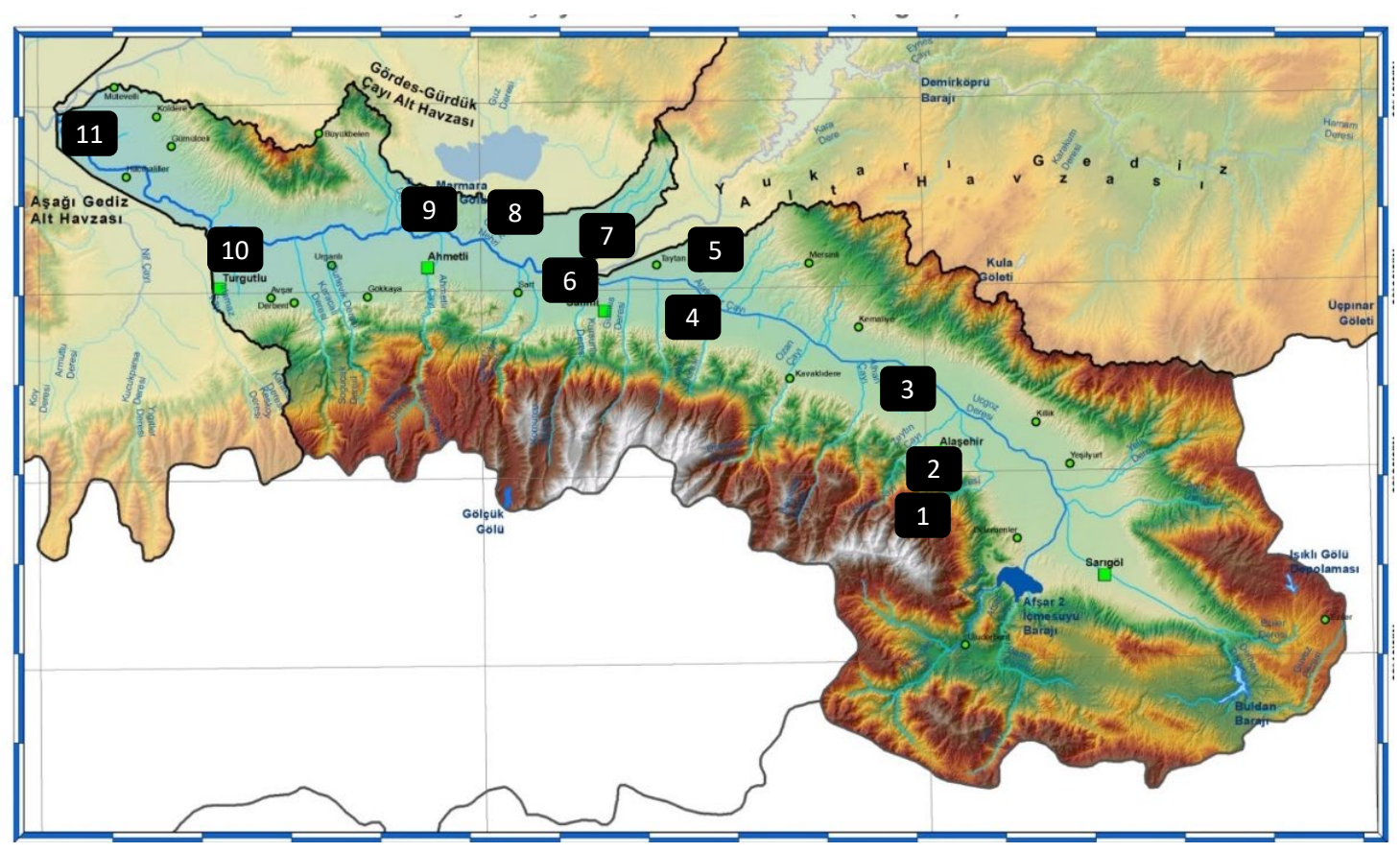

Şekil 1. Alaşehir Çayı Alt Havzası izleme istasyonları

Tablo 3. İzlenen parametreler, kullanılan yöntemler ve cihazlar

\begin{tabular}{|c|c|c|c|c|}
\hline Parametre adı & Analiz yöntemi & Analizin yapıldığı cihaz & $\begin{array}{c}\text { Tespit limiti } \\
\left(\mathrm{mg}^{-L^{-1}}\right)\end{array}$ & $\begin{array}{c}\text { Tayin limiti } \\
\left(\mathrm{mg} . \mathrm{L}^{-1}\right)\end{array}$ \\
\hline pH & SM $4500 \mathrm{H}+\mathrm{B}$ & Hach lange multimetre & yok & Yok \\
\hline İletkenlik & SM 2510 B & Hach lange multimetre & yok & Yok \\
\hline $\mathrm{O}_{2}$ doygunluğu & $\mathrm{SM} 4500 \mathrm{O}, \mathrm{G}$ & Hach lange multimetre & yok & Yok \\
\hline Çözünmüş $\mathbf{O}_{2}(C ̧ O)$ & $\mathrm{SM} 4500 \mathrm{O}, \mathrm{G}$ & Hach lange multimetre & yok & Yok \\
\hline Biyokimyasal oksijen ihtiyacı (BOİ & $\begin{array}{l}\text { SM } 5210 \text { B } 5 \text { Günlük BOİ } \\
\text { Test Metodu }\end{array}$ & WTW Multimetre & 0.3 & 3 \\
\hline Kimyasal oksijen ihtiyacı (KOİ) & SM 5220 B Açık Reflaks & $\begin{array}{l}\text { KOİ Isitıc1 Set, Otomatik } \\
\text { Titrasyon Cihazı }\end{array}$ & 3 & 10 \\
\hline Amonyum azotu $\left(\mathrm{NH}_{4}-\mathrm{N}\right)$ & $\mathrm{SM} 4500-\mathrm{NH}_{3} \mathrm{H}$ & $\begin{array}{l}\text { Scalar marka sürekli akış } \\
\text { analizörü }\end{array}$ & 0.003 & 0.010 \\
\hline Nitrit+Nitrat azotu $\left(\mathrm{NO}_{2}+\mathrm{NO}_{3}-\mathrm{N}\right)$ & $\mathrm{SM} 4500 \mathrm{NO}^{3-}: \mathrm{I}$ & $\begin{array}{l}\text { Scalar marka sürekli akış } \\
\text { analizörü }\end{array}$ & 0.003 & 0.010 \\
\hline Nitrit azotu $\left(\mathrm{NO}_{2}-\mathrm{N}\right)$ & $\begin{array}{ll}\mathrm{SM} \quad 4500 & \mathrm{NO}_{2}-\mathrm{B} \\
\text { Kolorimetrik Metot. } & \end{array}$ & Spektrofotometre & 0.0006 & 0.002 \\
\hline Toplam Kjeldahl azotu (TKN) & SM-4500 N org. & $\begin{array}{l}\text { Gerhardt Vadopest Distilasyon } \\
\text { Cihazı }\end{array}$ & 0.15 & 0.5 \\
\hline Toplam Fosfor (TP) & SM 4500 P: H & $\begin{array}{l}\text { Scalar marka sürekli akış } \\
\text { analizörü }\end{array}$ & 0.008 & 0.015 \\
\hline
\end{tabular}

\section{Bulgular ve tartışma}

\subsection{Noktasal ve yayll kaynaklı kirlilik yüklerinin hesaplanmast}

Alaşehir Çayı Alt Havzasındaki noktasal kaynaklı kentsel ve endüstriyel atıksu deşarjları dikkate alınarak, alıcı ortama ulaşan organik madde (KOİ), TN ve TP yükleri üzerinden değerlendirilmiştir. Alt havzada kentsel ve endüstriyel kirlenmeyi temsil eden noktasal kaynaklı TN, TP ve KOİ yükleri incelendiğinde, TN'nin \%93'ü, TP'nin $\% 95$ 'i ve KOİ'nin \%83'ü kentsel atıksu deşarjlarından geldiği görülmektedir. Havzada aritılmayan veya aritmadan sonra giderilemeyen kirlilik yükleri akarsulara deşarj edilmektedir. Noktasal kaynaklı kirliliğin önüne geçmek veya azaltabilmek endüstriyel ve kentsel atıksuların arıtılması ile mümkün olmaktadır. Literatürde yapılan çalışmalar incelendiğinde Eren ve Kaya (2020) tarafından yapılan bir araştırmada Erzurum iline KAAT kurulması öncesinde ve sonrasinda 
Karasu Nehri'nin su kalitesi incelenmiştir. Erzurum KAAT'nin $\mathrm{BOI}_{5}$, KOİ, AKM, TN parametrelerini \%90'ın üzerinde giderdiği belirlenmiş, Karasu'ya karışan KAAT debisinin mevsimsel dalgalanmaya göre Karasu'yun \%320 'sini oluşturduğu tespit edilerek, atıksu kalitesindeki iyileşmenin Karasu'yu önemli ölçüde etkilediği sonucuna varılmıştır (Eren ve Kaya, 2020). Hacisalihoğlu ve Karaer (2020) Bursa Uluabat Gölü'ne ulaşan noktasal kirlilik kaynakları ve göle olan etkisini çalışmışlardır. Göle ulaşan noktasal kirletici kaynakların kalitesi IV. Sınıf olarak tespit edilmiş ve gölü önemli ölçüde kirlettikleri belirlenmiştir (Hacısalihoğlu ve Karaer; 2020). Garipağaoğlu (2016) tarafindan Marmara Havzası için yapılan bir çalışmada TÜIKK, EPDK, İllerin Çevre Durum Raporları ve Havza Koruma Eylem Planında yer alan veriler üzerinden kentleşmeye bağlı atıksu oluşumu ve bunun alıcı ortam üzerindeki etkileri incelenmiştir. Havzadaki kirliliğin daha çok noktasal kaynaklardan geldiği ifade edilerek, havzadaki alıc1 ortam istasyonlarının yeterli sayıda olmadığı, dolayısıyla su kalitesinin yeteri kadar belirlenemediği ortaya konmuştur (Garipağaoğlu, 2016). Alaşehir Çay1 Alt Havzası için de işletmeye alınacak olan KAAT leri ile noktasal kaynaklı kirliliğin önemli ölçüde azalacağı tahmin edilmektedir. Mülga OSİB tarafindan TÜBİTAK MAM ile hazırlanan Havza Koruma Eylem Planlarının Hazırlanması Projesinde Alaşehir Çayı Alt Havzasının da içinde yer aldığ iyileştirmelerle noktasal kaynaklardan gelen KOİ yükünün yaklaşık $\% 50$, TN ve TP yüklerinin ise $\% 25$ oranında azalması tahmin edilmiştir (OSİB, 2013, Hazırlayan: TÜBİTAK MAM).

Alaşehir Çayı Alt Havzasındaki yayılı kaynaklı kirlilik gübre kullanımı, hayvancılık faaliyetleri, arazi kullanımı, fosseptik kullanımı, düzensiz depolama alanlarından kaynaklanan sızıntı suları ve atmosferik taşınım dikkate alınarak, alıcı ortama ulaşan TN ve TP yükleri üzerinden değerlendirilmiştir. Elde edilen bulgular 1şığında alt havzaya ulaşan yayılı TN yükleri esas olarak gübre kullanımından (\%37); hayvancıl1k faaliyetlerinden (\%34) ve arazi kullanımından (\%20) kaynaklanmaktadır. Atmosferik taşınımın (\%5), fosseptik kullanımının (\%2) ve sizıntı sularının (\%2) etkisi nispeten azdır. Yayılı TP yüklerinin kaynakları incelendiğinde gübre kullanımı (\%48) ve hayvancilik faaliyetlerinin (\%41) çok etkin olduğu görülmektedir. Yayılı TN kaynaklarından farklı olarak arazi kullanımının etkisi daha düşük oranlardadır (\%7).
Alaşehir Çayı Alt Havzası genelinde alıcı ortama ulaşan TN ve TP yüklerinin noktasal ve yayılı kaynaklardan ne oranda geldikleri karşılaştırıldığında, yayılı kaynaklardan gelen kirliliğin TN için \%79 ve TP için \%61 oranında daha fazla olduğu görülmektedir (Tablo 4). İki parametre kendi aralarında karşılaştırıldığında, TP yükünde noktasal kaynakların etkisinin TN yüküne göre nispeten daha fazla olduğu gözlenmektedir. $\mathrm{Bu}$ durum, noktasal TP yükünün önemli ölçüde kentsel atıksudan gelmesinden kaynaklanmaktadır. Oluşan kentsel atıksuyun bir kısmı arıtılmadan alıcı ortama ulaşmakta bir kısmı AAT'lerde arıtılmaktadır. Ancak arıtma havza genelinde ikinci kademe olarak yapıldığı için nütrient giderimi (özellikle TP giderimi) gerçekleşmemektedir.

Özalp (2009) tarafından Doğu Karadeniz Havzası yayılı kaynaklı kirleticileri incelenmiş, tarım faaliyetlerinin yayılı TN'nin \%54'üne ve TP'nin $\% 48$ 'ine karşl1ık geldiği; hayvancılık faaliyetlerinin (TN'nin \%11'i; TP'nin \%18'i) ikinci sırada yer aldığ 1 ortaya konmuştur. Mevcut çalışmadan farklı olarak fosseptik sularının özellikle fosfor parametresi (\%14) üzerinden daha kirletici olduğu gözlenmiştir. $\mathrm{Bu}$ durum KAAT'lerinin var olup olmaması ile ilişkilidir (Özalp, 2009). Benzer bir çalışma Aras Havzası için yapılmış yayılı TN yükü kaynakları \%33 hayvancilık, \%12 tarım faaliyetleri ve $\% 3$ fosseptik çıkış suları olarak; yayılı TP yükünün kaynakları ise $\% 40$ tarım, $\% 30$ hayvancılık, $\% 5$ fosseptik çıkış suları olarak bulunmuştur (Yontar, 2009). Daha yakın zamanlarda Ayyıldız (2019) tarafindan yapılan bir çalışmada Yeşilırmak Havzası kollarından biri olan Tersakan Çayında pestisit izlemesi yapılmış, incelenen 57 pestisitten 22'sinin kabul edilebilir Çevresel Kalite Standardı değerini geçtiği gözlenmiştir. Pestisitlerin bazılarının endüstriyel deşarjlardan geldiği tespit edilerek noktasal ve yayılı kirlilik kaynakları belirlenmiş, aralarında bir kıyaslama yapıldığında noktasal kaynaklı kirliliğin ihmal edilebilir ölçüde olduğu sonucuna varılmıştır (Ayyıldız, 2019). Hayvancılık faaliyetlerinden kaynaklanan kirliliğin belirlenmesi üzerine Mardin ve merkez ilçelerinde yapılan bir çalışmada büyükbaş, küçükbaş ve kümes hayvanlarından kaynaklanan $\mathrm{TN}$ ve TP yükleri belirlenmiştir (Derin vd., 2019). Mevcut çalışmada kullanılan metodolojiye benzer bir yöntem izlenerek yapılan hesaplamalar sonucunda Mardin ilçeleri arasında bir sıralama yapılmıştır (Derin vd., 2019).

Yayılı kaynaklı kirliliğin azaltılmasında organik tarım ve iyi tarım uygulamalarının artması, daha az ve bilinçli gübre kullanılması, hayvancılık 
faaliyetlerinde daha çok modern çiftliklerde besi hayvanı yetiştiriciliğine geçilmesi, katı atıkların bertarafında düzenli depolamaya geçilerek sızıntı sularının arıtılması gibi faaliyetlerin etkili olacağı düşünülmektedir. Mülga OSİB tarafindan TÜBİTAK MAM ile Gediz Havzası için yapılan
Havza Koruma Eylem Planın Hazırlanması Projesinde alınabilecek önlemlerle yayılı TN ve TP yükünün en fazla \%30 civarlarında azaltılabileceği belirlenmiștir (OSIBB, 2013, Hazırlayan: TÜBİTAK MAM).

Tablo 4. Alaşehir Çayı Alt Havzası TN ve TP yüklerinin noktasal ve yayılı kaynaklara göre karşılaştırılması

\begin{tabular}{|c|c|c|c|c|c|}
\hline & Kirlilik k & & (ton/yıl) & $(\%)$ & $(\%)$ \\
\hline \multirow{11}{*}{$\mathbf{T N}$} & Noktasal & Kentsel & 664 & 19 & \\
\hline & & Endüstriyel & 50 & 1 & \\
\hline & & Toplam & 714 & & 21 \\
\hline & Yayılı & Tarım Faaliyetleri & 1014 & 30 & \\
\hline & & Hayvancılık Faaliyetleri & 925 & 27 & \\
\hline & & Arazi Kullanımı & 540 & 16 & \\
\hline & & Atmosferik Taşınım & 125 & 4 & \\
\hline & & Düzensiz Depolama Alanları & 53 & 2 & \\
\hline & & Fosseptik Kullanımı & 49 & 1 & \\
\hline & & Toplam & 2706 & & 79 \\
\hline & Toplam & & 3420 & & 100 \\
\hline \multirow{10}{*}{ TP } & Noktasal & Kentsel & 123 & 38 & \\
\hline & & Endüstriyel & 6 & 2 & \\
\hline & & Toplam & 129 & & 39 \\
\hline & Yayılı & Tarım Faaliyetleri & 95 & 29 & \\
\hline & & Hayvancılık Faaliyetleri & 82 & 25 & \\
\hline & & Arazi Kullanımı & 14 & 4 & \\
\hline & & Düzensiz Depolama Alanları & 1 & 0 & \\
\hline & & Fosseptik Kullanımı & 7 & 2 & \\
\hline & & Toplam & 199 & & 61 \\
\hline & Toplam & & 328 & & 100 \\
\hline
\end{tabular}

\subsection{Yüzeysel su kalitesi}

Alaşehir Çayı Alt Havzasında, alıcı ortamın kalitesini belirlemek amaciyla dört mevsimi temsil edecek şekilde; Kasım 2015 (sonbahar), Şubat 2016 (kış), Mayıs 2016 (ilkbahar) ve Ağustos 2016 (yaz) dönemlerinde izlemeler gerçekleştirilmiştir. İzleme çalışmaları Alaşehir, Salihli, Sarıgöl, Ahmetli ve Turgutlu ilçelerindeki nehir istasyonlarında yürütülmüştür. Elde edilen sonuçlar YSKY'de Ek 5, Tablo 2' de yer alan Konvansiyonel Parametrelere göre değerlendirilmiştir. İzleme yapılan dört dönemin ortalama sonuçlarına göre incelenen 11 istasyondan ikisi (3 ve 5. istasyonlar) dört dönem boyunca kuru olarak tespit edilmiş, 4 istasyon çok kirlenmiş su kalitesinde (Sınıf IV), 2 istasyon kirlenmiş su kalitesinde (Sınıf III), 2 istasyon az kirlenmiş su kalitesinde (Sınıf II) bulunmuştur.

Alaşehir Çayı Alt Havzasında membaya en yakın nokta olarak izleme yapılan 1. istasyon (Asar Deresi) KOİ, BOİ, TKN, TP açısından Sınıf II (az kirlenmiş su) su kalitesindedir. Asar Deresi üzerinde olan ve endüstri ve kentsel deşarjlar sonrasında yer alan 2. İstasyonda (Alaşehir AAT deşarj1 öncesi) KOİ, BOİ, $\mathrm{NH}_{4}, \mathrm{TKN}$, TN, TP parametreleri açısından su kalitesi Sınıf IV (çok kirlenmiş su) olarak belirlenmiş̦tir. Alaşehir Çayı üzerinde olan 4.istasyonda (Salihli OSB deșarj1 öncesi) KOİ, $\mathrm{NH}_{4}$, TKN, TP parametrelerine bağlı olarak Sınıf IV (çok kirlenmiş su) su kalitesi gözlenmiştir. Alaşehir Çayının Gediz Nehrine bağlanmasından önce yer alan 6.istasyon (Salihli KAAT ve Salihli Dericiler deşarjlarının sonrası), çözünmüş oksijen (ÇO), KOİ, BOİ 5 , TKN, TP açısından Sınıf IV (çok kirlenmiş su) su kalitesinde bulunmuştur. Alaşehir Çayı Alt Havzası için membada nispeten az kirlenmiş su (Sınıf II) olarak gözlenen su kalitesinin, 1.isatsyondan itibaren, 6. istasyona kadar su kalitesinin kötüleştiği gözlenmektedir. $\mathrm{Bu}$ durumun bölgedeki tarım faaliyetleri ile evsel ve endüstriyel deşarjlardan kaynaklandığı düşünülmektedir. 7. istasyon Demirköprü Barajı çıkan kolun Gediz Nehri ile birleşimi öncesinde ölçülmüş ve Sınıf II kalitesinde bulunmuştur. Benzer şekilde Gölmarmara'dan çıkan ve Gediz Nehrine karışım öncesinde izleme yapilan 8.istasyonda su kalitesi Sinif II olarak gözlenmiştir. Ahmetli civarlarında Gediz Nehri üzerinde olan 9. istasyonda (Ahmetli KAAT deşarjı öncesi) su kalitesi Sınıf III olarak tespit 
edilmiştir. Bu durum Demirköprü Barajından ve Gölmarmara'dan çıkan ve Gediz Nehrine ulaşan suların nispeten daha temiz olması ile ve bu suların Gediz Nehrini seyreltmesi ile ilişkilendirilmektedir. 9. istasyonda su kalitesini III. Sınıf olarak belirleyen parametreler çözünmüş oksijen, KOİ, $\mathrm{BOI}_{5}$, TKN ve TP olmuştur. 10. istasyon Turgutlu'dan Gediz Nehrine karışan suyu temsil etmekte olup, buradaki su kalitesi ÇO, $\mathrm{BOI}_{5}$ ve TP'ye bağlı olarak Sınıf IV bulunmuştur.
Alaşehir Çayı Alt Havzası sınırları içinde son izleme noktası Manisa Merkez öncesindeki 11. istasyon olmuş ve su kalitesi ana koldaki durumu takip eder şekilde Sınıf III olarak belirlenmiş ve belirleyici parametre TP olmuştur. Alaşehir Çayı Alt Havzasinda dört dönem izlenen KOİ, TN ve TP parametreleri Tablo 5'de, tüm parametrelerin ortalama değerleri üzerinden elde edilmiş su kalitesi haritası ise Şekil 2'de sunulmaktadır.

Tablo 5. Alaşehir Çayı Alt Havzası istasyonlarında dört dönem boyunca izlenen KOİ, TN ve TP parametreleri

\begin{tabular}{|c|c|c|c|c|c|c|c|c|c|c|c|c|c|}
\hline \multirow[t]{2}{*}{ İstasyon } & \multirow[t]{2}{*}{ Yerleşim } & \multicolumn{3}{|c|}{ 1.Dönem } & \multicolumn{3}{|c|}{ 2.Dönem } & \multicolumn{3}{|c|}{ 3.Dönem } & \multicolumn{3}{|c|}{ 4.Dönem } \\
\hline & & KOİ & $\mathrm{TN}^{*}$ & $\mathrm{TP}$ & KOİ & $\mathrm{TN}^{*}$ & $\mathrm{TP}$ & KOİ & $\mathrm{TN}$ & $\mathrm{TP}$ & KOİ & $\mathrm{TN}^{*}$ & $\mathrm{TP}$ \\
\hline 1 & Manisa-Alaşehir & 29.00 & 0.90 & 0.09 & 33.00 & 1.80 & 0.10 & 22.00 & 1.01 & 0.08 & 26.00 & 0.75 & 0.05 \\
\hline 2 & Manisa-Alaşehir & 71.00 & 35.87 & 21.49 & 154.00 & 8.70 & 0.60 & 442.00 & 27.62 & 2.09 & 330.00 & 42.67 & 20.45 \\
\hline 3 & Manisa-Alaşehir & & & & & & & & & & & & \\
\hline 4 & Manisa-Salihli & 88.00 & 15.08 & 2.69 & 28.00 & 3.43 & 0.28 & 126.00 & 18.89 & 2.94 & & & \\
\hline 5 & Manisa-Salihli & & & & & & & & & & & & \\
\hline 6 & Manisa-Salihli & 272.00 & 17.66 & 2.88 & 43.00 & 3.58 & 0.30 & 42.00 & 4.61 & 0.80 & 27.00 & 2.39 & 0.45 \\
\hline 7 & Manisa-Salihli & 80.00 & 1.39 & 0.07 & 10.00 & 2.23 & 0.11 & 16.00 & 1.23 & 0.15 & 14.00 & 1.01 & 0.07 \\
\hline 8 & Manisa-Salihli & 14.00 & 0.79 & 0.04 & 21.00 & 1.17 & 0.11 & 15.00 & 0.80 & 0.13 & 24.00 & 0.96 & 0.04 \\
\hline 9 & Manisa-Ahmetli & 85.00 & 9.71 & 1.81 & 13.00 & 3.15 & 0.29 & 78.00 & 4.76 & 0.74 & 27.00 & 1.06 & 0.10 \\
\hline 10 & Manisa-Turgutlu & & & & 40.00 & 3.33 & 0.69 & 112.00 & 5.51 & 1.81 & 25.00 & 1.32 & 0.21 \\
\hline 11 & Manisa-Şehzadeler & 5.00 & 2.99 & 0.62 & 10.00 & 2.19 & 0.17 & 22.00 & 1.88 & 0.24 & 19.00 & 1.11 & 0.13 \\
\hline
\end{tabular}

* TN değeri, su numunelerinde izlenen TKN ve oksitlenmiş azot formlarının toplamından elde edilmiştir.

$\mathrm{Su}$ kalitesinde kirlenmenin tespit edildiği noktalarda, kirlilik unsurunun noktasal kaynaklı kirleticilerden mi yoksa yayılı kaynaklı kirleticilerden mi kaynaklandığını gösteren en önemli ipucunun organik parametreler olduğu görülmektedir. Organik parametrelerin tespitinde kirliliğin noktasal kaynaklardan geldiğini söylemek mümkün olmaktadır. Kirlilik yükleri ile su kalitesi için elde edilen sonuçlar karşılaştırıldığında, noktasal ve yayılı kirleticilerin bulunduğu alanlardan geçen akarsuların su kalitesinin kötüleştiği tespit edilmektedir. Noktasal kaynaklar organik madde, azot ve fosfor açısından kirliliğe sebep olurken, yayılı kaynaklar özellikle azot ve fosfor kirliliğine sebep olmaktadır.

Literatürde yer alan çalışmalar incelendiğinde Alaşehir Çayı Alt Havzası özelinde olmasa da Gediz Havzası genelinde su kalitesi pek çok çalışmada konu edinilmiştir. Bu çalışmaların bir k1smında konvansiyonel kirleticileri tespit etmek (Süzal ve Bizsel, 2008; Çetin vd.,2009; Öner ve Çelik, 2011; Kıymaz, 2018), bir kısmında da havzadaki yüzey sularında ağır metal içeriğini tespit etmek (Küçüksezgin vd., 2008; Minareci vd., 2009; Aydın ve Küçüksezgin 2012; Bizsel vd., 2017) hedeflenmiştir. Ancak bu çalışmaların yanı sıra uzun süreli ve periyodik olarak yapılan DSİ izlemelerinin mevut çalışma için 1 şı tutacağı düşünülmektedir. DSİ'nin 2000-2014 yıllarına ait su kalitesi izleme sonuçları, YSKY Tablo 5'teki tüm parametrelere göre değerlendirildiğinde havzadaki su kalitesinin ağırlıklı olarak Sınıf III ve Sınıf IV seviyesinde olduğu tespit edilmiştir. Alaşehir Çayı Alt Havzası incelendiğinde Alaşehir Çayı üzerinde nerdeyse hiç gözlem istasyonu olmadığ 1 , Gediz Nehri üzerinde Salihli'den itibaren izleme yapıldığı görülmüştür. $\mathrm{Bu}$ istasyonlar $\mathrm{pH}$, ÇO, amonyum azotu, nitrit azotu ve renk parametreleri açısından çok kirlenmiş su (Sınıf IV) özelliği göstermiştir (Mülga Orman ve Su İşleri Bakanlığı, 2015). DSİ izleme sonuçları ile mevcut çalışmadaki izleme sonuçları karşılaştırıldığında havzadaki su kalitesinin 2000'li y1llardan itibaren iyi olmadığı görülmektedir. DSİ tarafindan organik içeriğin belirlenmesine yönelik değerlendirmelerde genellikle KOİ ve BOİ parametreleri dikkate alınmaktadır. Diğer organik parametreler ölçülmediği için gerçek su kalitesinin bilinenden daha kötü olabileceği düşünülmektedir. Ayrıca endüstrinin yoğunlaştığı belirli alanlarda, ağır metallerin ölçümü çok önemlidir. Havza genelinde su kalitesi izleme ağının genişletilmesi ve izlenen su kalitesi parametrelerinin sayısının artırılması 
şiddetle tavsiye edilmektedir. Ayrıca uzun dönemli su kalitesi hakkında bilgi veren ekolojik ve biyolojik kirliliğin ölçülmesine yönelik parametreler de belirlenmelidir.

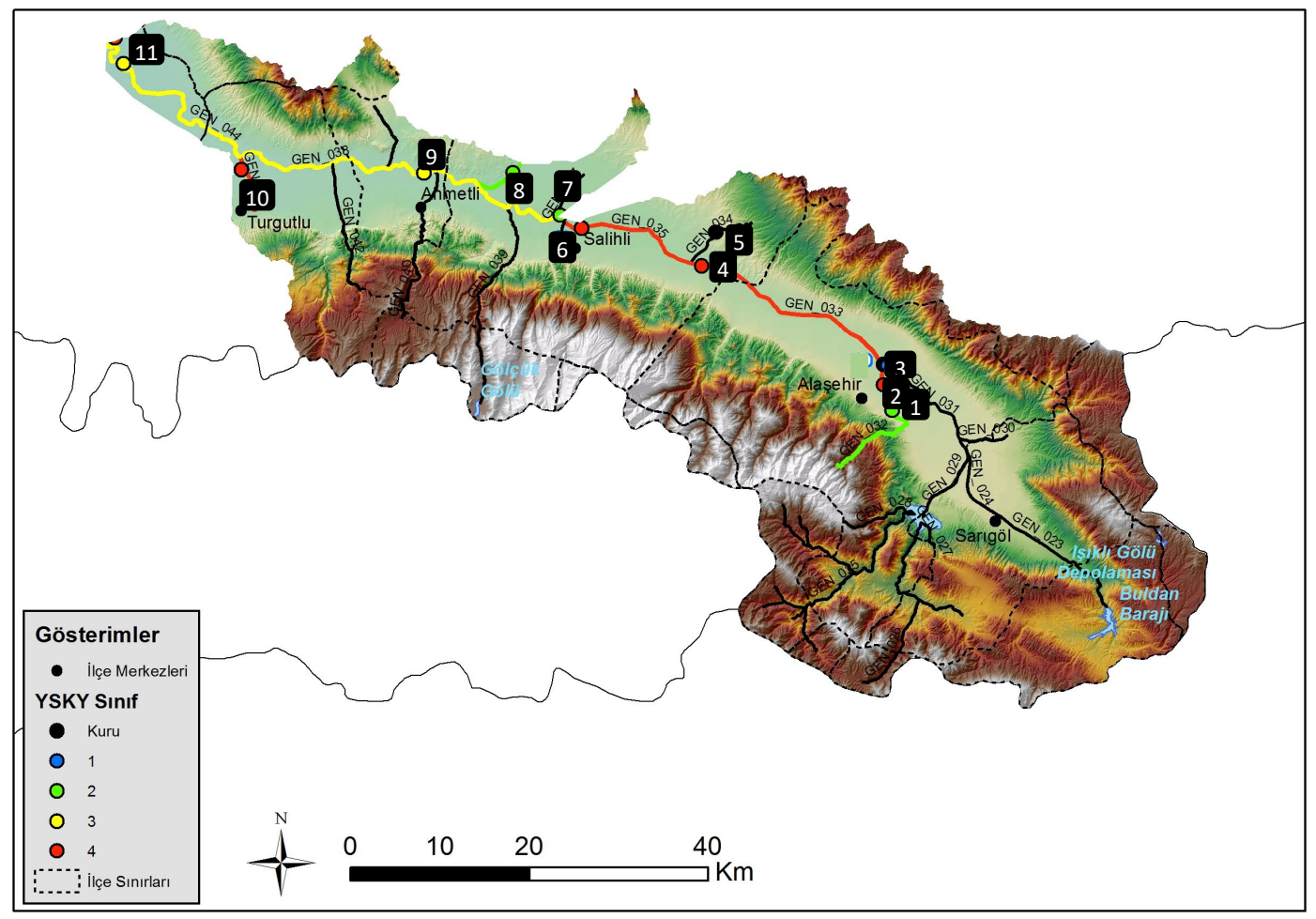

Şekil 2. Alaşehir Çayı Alt Havzası yüzeysel su kalitesi

\section{Sonuçlar}

Mevcut çalışma ile Alaşehir Çayı Alt Havzasına noktasal ve yayılı kirletici kaynakların sebep olduğu kirliliğin belirlenmesi için kolaylıkla uygulanabilir bir hesap yöntemi sunulmuş, ardından noktasal ve yayılı kaynaklı kirleticilerin yüzeysel su kalitesi üzerine etkisi incelenmiştir. Elde edilen sonuçlar ışığında aşağıdaki sonuçlar elde edilmiştir;

- Alt havzadaki noktasal ve yayıli kirletici kaynaklar karşılaştırıldığında, havzada oluşan toplam TN yükünün \%79'u, TP yükünün ise $\% 61$ ' $\mathrm{i}$ yayılı kaynaklı faaliyetlerden gelmektedir.

- Havza genelinde yayılı kaynaklı kirliliğin oluşumunda en fazla gübre kullanımının (TN'nin \%37'si, TP'nin \%48'i) ve hayvancilık faaliyetlerinin (TN'nin \%34'ü, TP'nin \%41'i) etkili olduğu gözlenmiştir.

- Havza genelinde noktasal kirlilik yükleri TN, TP ve KOİ parametreleri üzerinden değerlendirilmiş, kentsel ve endüstriyel baskılar arasında kentsel atıksu deşarjlarının
TN'nin \%93'üne, TP'nin \%95'ine ve KOİ'nin \%83'üne karşıllk geldiği belirlenmiştir.

- Havzada izleme yapılan 11 yüzey suyu istasyonundan 4'ü çok kirlenmiş su kalitesinde (Sınıf IV) ve 3'ü kirlenmiş su kalitesinde (Sınıf III) bulunmuştur. En kirli olarak tespit edilen istasyonlar Alaşehir, Salihli ve Turgutlu çıkışlarında belirlenmiştir.

- Noktasal ve yayılı kirlilik yükleri ile su kalitesi sonuçları karşılaştırıldığında, noktasal ve yayılı kirleticilerin bulunduğu alanlardan geçen akarsuların su kalitesinin kötüleştirdiği, Demirköpürü Barajından ve Gölmarmara'dan çıkan suların seyreltme etkisi ile Gediz Nehrinin su kalitesinin belli bir ölçüde iyileştiği sonucuna varılmıştır.

Çalışmada sunulan sonuçlar ile Alaşehir Çayı Alt Havzası için olası kirleticiler ve su kalitesine olan etkileri ortaya konmuştur. Kirlilik yüklerinin hesaplanmasında sunulan yöntem ile alanda çalışan ilgili araştırmacılar için bir yol haritası çizileceği umulmaktadır. Diğer taraftan kirliliğin hangi kaynaktan geldiğine ve su kalitesinin hangi sebeplerden kirlendiğine işaret eden bu çalışmanın karar vericiler ve uygulayıcılar için yol gösterici olacağ 1 düşünülmektedir. 


\section{Teşekkür}

Mevcut çalışma, Mülga Orman ve Su İşleri Bakanlığı yürütücülügünde ve TÜBİTAK MAM Çevre ve Temiz Üretim Enstitüsü bünyesinde gerçekleştirilen Proje verilerinden türetilmiştir. Çalışmada emeği geçen başta Dr. Yakup KARAASLAN ve Su Yönetimi Genel Müdürlügü çalışanları ile TÜBİTAK MAM Havza Ekibi, Laboratuvar Ekibi ve CBS ekibine teşekkürlerimizi sunariz.

\section{Kaynaklar}

Agricultural Statistics (2001). Animal waste, Wyoming Agricultural Statistics Service, 2001 Wyoming Agricultural Statistics. Erişim adresi www.wyomingbusiness.org/pdf/energy/biomass 3.pdf

Akdoğan, Z., Küçükdoğan, A. ve Güven, B. (2015). Yayılı kirleticilerin havzalardaki taşınım süreçleri: Antibiyotikler, ağır metaller ve besi maddeleri üzerine modelleme yaklaşımları. Marmara Fen Bilimleri Dergisi, 27(1), 21-31.

Andreadakis, A., Gavalakis, E., Kaliakatsos, L., Noutsopoulos, C. and Tzimas, A. (2007). The implementation of the Water Framework Directive (WFD) at the river basin of Anthemountas with emphasis on the pressures and impacts analysis. Desalination, 210(1-3), 115. https://doi.org/10.1016/j.desal.2006.05.027

Aydın S. and Küçüksezgin F. (2012). Distribution and chemical speciation of heavy metals in the surficial sediments of the Bakırçay and Gediz Rivers. Eastern Aegean, 65(3), 789-803. https://doi.org/10.1007/s12665-011-1124-7

Ayyıldı, C. (2019). Estimation of diffuse pollution loads of pesticides in Tersakan Sub-Basin of Yeşilırmak River. Doktora Tezi, Ortadoğu Teknik Üniversitesi, Ankara.

Bizsel, N., Ardelan, M. V., Bizsel, K. C, Suzal, A., Demirdag, A. and Sarica, D.Y. (2017). Distribution of selenium in the plume of the Gediz River, Izmir Bay, Aegean Sea. Journal of Marine Research, 75(2), 81-98. https://doi.org/10.1357/002224017821352650

Bottcher, D. and Rhue, D. (2000). Fertilizer Management - Key to a Sound Water Quality Program, circular 816, Florida Cooperative Extension Service, Institute of Food and Agricultural Sciences, University of Florida.

Carneiro, L., Ostroski, A. and Mercuri, E. G. F. (2020). Trophic state index for heavily impacted watersheds: modeling the influence of diffuse pollution in water bodies. Hydrological Sciences $\begin{array}{lrr}\text { Journal, } & 65(15), & 2548-2560 . \\ \text { https://doi.org/10.1080/02626667.2020.1828588 }\end{array}$

CORINE (2012). European Environment Agency CORINE Land Cover Nomenclature Illustrated Guide (2012)

ÇOB (Çevre ve Orman Bakanlı̆̆ı, 2004). Su Kirliliği Kontrolü Yönetmeliği, 31 Aralık 2004, RG No: 25687.

ÇOB (Çevre ve Orman Bakanlığı, 2010). Atıksu Arıtma Tesisleri Teknik Usuller Tebliği, 20 Mart 2010, RG No: 27527.

Dahl S, Kurtar B (1993) Environmental Situation, Working Paper, No: 21. Omerli-Elmali environmental protection project-feasibility report, Omerli-Elmali Joint Venture 1.1-5.10, Istanbul.

DSİ (Devlet Su İşleri, 2021). Toprak ve Su Kaynakları. Erişim adresi https://www.dsi.gov.tr/Sayfa/Detay/754

du Plessis, A. (2019). Current and Future Water Scarcity and Stress. A. du Plessis (Ed.), Water as an Inescapable Risk, (s. 13-25). Switzerland: Springer, Cham.

Eren, Z. ve Kaya, F. (2020). Firat-Dicle Havza Koruma Eylem Planı çerçevesinde kentsel atıksu arıtma tesisinin Karasu Nehrinin su kalitesi üzerindeki etkisinin incelenmesi. Ulusal Çevre Bilimleri Araştırma Dergisi, 3(2), 95-109.

Ertürk, A., Gurel, M., Ekdal, A., Tavsan, C., Seker, D.Z., Cokgor, E.U., Insel, G., Mantas, E.P., Aydin, E., Ozgun, H., Cakmakci, M., Tanik, A. and Ozturk, I. (2007). Estimating the impact of nutrient emissions via water quality modelling in the Melen watershed. IWA 11th Diffuse Pollution Conference Proceeding No: 167, 26-31 August, Belo Horizonte, Brazil.

Falkenmark, M. (1989). The massive water scarcity now threatening Africa: Why isn't it being addressed? AMBIO, 18(2), 112-118.

Garipağaoğlu, N. (2016). Marmara Havzası'nda kentleşme-atık su ilişkileri ve alıcı ortam üzerindeki etkileri. Marmara Coğrafya Dergisi, (34), 147-159.

Gıda Tarım ve Hayvancılık Bakanlığı (2015). Illçelere Göre Gübre Kullanım Verileri

Gürel, M., Ertürk, A., Şeker, D. Z., Tanık, A., Ekdal, A., Avşar, C. and Özturk, I. (2011). Estimation of monthly diffuse nutrient loads for a watershed in Turkey. Water and Environment Journal, 25(2), 219-229. https://doi.org/10.1111/j.17476593.2009.00214.x 
Hacısalihoğlu, S. ve Karaer, F. (2020). Uluabat Gölü noktasal kirletici kaynaklar ve kirlilik yükleri. Doğal Afetler ve Çevre Dergisi, 6(2), 258-267. https://doi.org/10.21324/dacd.602385

Kıymaz, G. (2018). Aşă̆ Gediz Havzası nehir sularının kalitesinin değerlendirilmesi ve fizikokimyasal parametrelerin makroomurgasız üzerine etkilerinin incelenmesi. Yüksek Lisans Tezi, Hacettepe Üniversitesi Fen Bilimleri Enstitüsü, Ankara.

Luo, T., Robert, Y. and Reig P. (2015). Aqueduct Projected Water Stress Country Rankings, World Resources Institute, p.1-16.

Meteoroloji Genel Müdürlüğü (2016). Illere Göre Yağış Verileri. Erişim adresi https://www.mgm.gov.tr/veridegerlendirme/ilve-ilceler-istatistik.aspx? $k=A$

Oenema, O. and Roest, W. J. (1998) Nitrogen and phosphorous losses from agriculture into surface waters: the effects of policies and measures in the Netherlands. Water Sci. Technol., 37(2), 19-30. https://doi.org/10.1016/S0273-1223(98)00052-3

OSİB (Orman ve Su İşleri Bakanlığı, 2013). Gediz Havzası Koruma Eylem Planı Final Raporu, Hazırlayan: TÜBİTAK MAM, Ankara.

OSİB (Orman ve Su İşleri Bakanlığ1, 2015). DSI tarafindan 2000-2014 yillart arasinda yapilan Gediz Havzası Yüzeysel Su Kalitesi İzleme Sonuçları, Ankara.

OSİB (Orman ve Su İşleri Bakanlığı, 2016). Yerüstü Su Kalitesi Yönetmeliği, 10 Ağustos 2016, RG No: 29797.

Ouyang, W., Gao, X., Wei, P., Gao, B., Lin, C. and Hao, F. (2017). A review of diffuse pollution modeling and associated implications for watershed management in China. Journal of Soils and Sediments, 17(6), 1527-1536. https://doi.org/10.1007/s11368-017-1688-2

ÖEJV (1993). Ömerli-Elmall joint venture/ protection Ömerli and Elmall environmental protection project, feasibility study, progress report, İstanbul Water and Sewerage Administration.
Öner, Ö. ve Çelik, A. (2011). Gediz Nehri Aşağı Gediz Havzası'ndan alınan su ve sediment örneklerinde bazı kirlilik parametrelerinin incelenmesi. Ekoloji, 20(78), 48-52. https://doi.org/10.5053/ekoloji.2011.788

Özalp, D. (2009). Doğu Karadeniz Havzası'nda yayıl kirletici kaynakların belirlenmesi ve yönetim önerileri. Yüksek Lisans Tezi, İstanbul Teknik Üniversitesi Fen Bilimleri Enstitüsü, İstanbul.

Özcan, Z., Kentel, E. and Alp, E. (2016). Determination of unit nutrient loads for different land uses in wet periods through modelling and optimization for a semi-arid region. Journal of Hydrology, 540 , 40-49. https://doi.org/10.1016/j.jhydrol.2016.05.074

Öztürk, İ. (2008). Büyük İstanbul İçmesuyu Projesi II. Merhale Melen Sistemi Büyük Melen Havzası Entegre Koruma ve Su Yönetimi Master Planı, İstanbul Teknik Üniversitesi.

Tanık, A., Ozalp, D. and Seker, D. Z. (2013). Practical estimation and distribution of diffuse pollutants arising from a watershed in Turkey. International Journal of Environmental Science and Technology, 10(2), 221-230. https://doi.org/10.1007/s13762-012-0140-9

Türkiye İstatistik Kurumu. (2016). İlçelere Göre Büyükbaş, Küçükbaş ve Kanatlı (Tavuk) Hayvan Sayllarl. Erişim adresi https://biruni.tuik.gov.tr/medas/?locale $=\operatorname{tr}$

Yıldırım, Ü. (2020). Kaynağından Akdeniz'e Deliçay’ın (Mersin) Debisi ve su kalitesinin değerlendirilmesi. Gümüşhane Üniversitesi Fen Bilimleri Enstitüsü Dergisi, 10(4), 1121-1135. https://doi.org/10.17714/gumusfenbil.732106

Yontar, B. (2009). Aras Havzası'nda yayılı kirletici kaynakların belirlenmesi ve yönetim önerileri. Doktora Tezi, İstanbul Teknik Üniversitesi Fen Bilimleri Enstitüsü, İstanbul.

Zeydan, Ö., Özdoğan, N., Taştepe, P. Ş., ve Demirtaş, D. (2019). Kozlu Deresinde (Zonguldak) su kalitesinin incelenmesi. Doğal Afetler ve Çevre Dergisi, 5(2), 187-19. https://doi.org/10.21324/dacd.451775 